\title{
Social epidemiology of chickenpox in two British national cohorts
}

\author{
Jon I Pollock, J Golding
}

\begin{abstract}
Study Objective-To provide a quantitative description of factors independently predictive of reported chickenpox infections in two national cohorts of British children.

Design-Longitudinal cohort study design employing logistic regression analysis of data obtained in the 1970 British Births Survey (later to become the Child Health and Education Study, CHES), and the 1958 British Perinatal Mortality Survey (later to become the National Child Development Survey, NCDS).

Settings-One-week birth cohorts covering the whole of the United Kingdom.

Participants-Data were obtained from questionnaires administered to the carers of 10196 children born in the UK between 5 and 11 April 1970 (CHES) and 10927 children born in the UK between 3 and 9 March 1958 (NCDS). These numbers consist of the whole of the surviving cohorts excluding those for whom data were incomplete.
\end{abstract}

Measurements-Biological, social, and medical factors in the parents and children, as recorded by the child's principle carer or from clinical notes.

Main results-Chickenpox by the age of 10 years was reported to be more common in the children of advantaged families (higher social class, higher parental education levels), with a higher prevalence in those parts of the United Kingdom normally associated with affluence, such as the South East and South West of England, and lower rates in Wales and Scotland. Chickenpox by 10 years was also associated with more crowding in the home. A similar but less marked pattern occurred for chickenpox by the age of 11 years in the 1958 NCDS cohort. This social distribution apparently reflected overall rather than age-specific susceptibility.

Conclusions-The national and international pattern of chickenpox epidemiology indicate that both social and climatological factors may be important in defining groups at risk. Further research is indicated if a vaccination service is to be implemented in this country.

f Epidemiol Community Health 1993; 47: 274-281

Chickenpox has received relatively little attention from public health doctors or epidemiologists either at home or abroad. It is generally perceived to be a common contagious childhood disease with relatively benign morbidity. Serious sequelae such as pneumonia, encephalitis, or cerebella ataxia are rare ${ }^{1}$ unless an infant develops a neonatal infection contracted from a mother infected during pregnancy. Some reports have linked varicella with the development of cancer in animals ${ }^{2} 3$ but this association remains unproved in humans.

Data from the Royal College of General Practitioner's Research Unit indicate that in England and Wales $0.5 \%$ of the population, about 200000 in all, contract chickenpox each year on average, of whom about $1000(0 \cdot 5 \%)$ are admitted to hospital as a result of associated complications. ${ }^{4}$ The average annual number of deaths from chickenpox between 1967 and 1985 was 20 in England and Wales. This period included the two epidemics around 1971 and $1980 .{ }^{4}$ As is the case with measles, it is often the immunosuppressed patient who suffers most. Despite the normally inconsequential course of the infection the overall national social and economic burden of chickenpox is substantial. ${ }^{5}$

From the clinical and epidemiological perspective, chickenpox is of great interest as the varicella-zoster virus has the capability of silent residence in a variety of neural ganglia for much of a lifetime. On reactivation by unknown factors it causes skin lesions known as "zoster" and also shingles, a painful neuralgia that afflicts many adults, especially the elderly. For these reasons the prospect of vaccination has been considered but as Joseph and Noah ${ }^{4}$ point out basic information on the incidence and severity of varicella and zoster disease remains to be collected. Several studies and numerous case reports have indicated that the population distribution of infections and susceptibility to chickenpox in developing countries contrasts substantially with the experience of the industrialised world. $^{6}$ Additional information about the epidemiology of the disease and the identification of those most at risk in the industrialised nations, where vaccination is likely to be most cost effective, would aid such decicisions. The present report is a contribution to this topic.

\section{Methods}

The present study uses data from the 1958 and 1970 national cohort studies henceforth called respectively the National Child Development study (NCDS) and the Child Health and Education Study (CHES). These were both started as cross sectional studies undertaken on all of the approximately 17000 mothers who gave birth to babies throughout the UK, in one complete week in spring. ${ }^{7-9}$ The original objective was to understand better the factors associated with maternal and infant morbidity at and around the 
time of birth. Later, the same cohorts of births were used in longitudinal studies as the surviving children were followed up at 7 and 11 years (NCDS) and 5 and 10 years (CHES).

At both 7 and 11 years of age (NCDS) and at 10 years (CHES), the mothers or carers of the children were asked whether their child had ever had chickenpox. These questions were asked by a health professional in the home who completed the questionnaire and could answer any queries. In the CHES questionnaire, the age at which the child had had chickenpox was also obtained.

1970 NATIONAL COHORT (CHES)

Social, demographic, and biological factors relating to reported chickenpox infection in the CHES cohort were initially investigated by cross tabulating 73 background variables with a history of the disease by 10 years of age. No prior selection of background variables was made as there was no a priori reason for favouring some social, demographic, or biological factors over others. The data on chickenpox used in this cohort include information from the 241 cases of chickenpox reported to have occurred shortly after the child's 10th birthday, representing the time between the questionnaire presentation date and its completion. From the original birth cohort of 16120 (which excludes deaths $<1$ week post partum and babies born in Northern Ireland), 10196 cases

Table I Background factors significantly $(p<0.05)$ associated with reported chickenpox by 10 years of age in the CHES cohort

\begin{tabular}{|c|c|}
\hline Group & Factor $^{\star}$ \\
\hline (1) Mother's background & $\begin{array}{l}\text { Region of delivery }{ }^{1234} \\
\text { Place of birth of infant } \\
\text { Place of birth of mother } \\
\text { Age mother lefi full-time education }{ }^{1234} \\
\text { Mother's occupational class }{ }^{123} \\
\text { Mother's age } \\
\text { Mother's height } \\
\text { Highest educational qualification }(1975)^{1}\end{array}$ \\
\hline (2) Father's background & $\begin{array}{l}\text { Place of birth of father } \\
\text { Age father left full-time education } \\
\text { Father's ethnic origin }{ }^{1}{ }^{1} 4 \\
\text { Father's occupational class }(1970)^{1234} \\
\text { Father's occupational class (1975) } \\
\text { Father's age } \\
\text { Father's employment status } \\
\text { Highest educational qualification (1975) } \\
\text { Either parent's highest qualification (1975) }\end{array}$ \\
\hline (3) Circumstantial & $\begin{array}{l}\text { Present marital status } \\
\text { Marital status at conception }{ }^{1} \\
\text { Number of rooms in household in } 1975 \\
\text { Number of persons in household in } 1975^{134} \\
\text { Persons per room ratio in } 1975^{12}\end{array}$ \\
\hline (4) Reproductive history & $\begin{array}{l}\text { Number of previous pregnancies } \\
\text { Number of previous early neonatal deaths } \\
\text { Number of older children in household (1975) } \\
\text { Parity }{ }^{12} \\
\text { Interval between births }{ }^{124} \\
\text { Interval between pregnancies } \\
\text { Contraceptive method previously used } \\
\text { Certainty of last menstrual period dates } \\
\text { Believability of last menstrual period dates }\end{array}$ \\
\hline (5) Present pregnancy & $\begin{array}{l}\text { Present smoking habits } \\
\text { Present or past smoking habits } \\
\text { Lowest haemoglobin count } \\
\text { Date of first antenatal care visit }{ }^{1} \\
\text { Person responsible for antenatal care }{ }^{1} \\
\text { Mother's asthma or hayfever } \\
\text { Any labour preparation class attendance }^{12} \\
\text { Attended labour classes in health clinic }^{2} \\
\text { Place of delivery }^{1} \\
\text { Antenatal visit rate }\end{array}$ \\
\hline (6) Birth & $\begin{array}{l}\text { Birth weight } \\
\text { Resuscitation of infant } \\
\text { Separation of mother from infant after birth } \\
\text { Gestational age at delivery } \\
\text { Attempted breastfeeding } \\
\text { Feeding pattern in first week } \\
\text { Breastfeeding during first } 3 \text { months } s^{12} \\
\text { Feeding pattern over first } 3 \text { months }\end{array}$ \\
\hline
\end{tabular}

* Superscripts refer to the round of regressions the factor remained in the model for. Factors in italic remained in the final model-see text. were selected for study. This comprised all survivors with data available from each of the three time points $(0,5$, and 10 years), where the child's immunisation history was known, and where chickenpox was either reported as having occurred at a specified age or was reported as not having occurred at all. The group lost to follow up in survivors in this cohort included a disproportionate number of unmarried mothers who smoked and mothers living in the South East of England. Only 121 cases were lost because the parent did not know whether the child had had chickenpox or not and 178 cases were lost because chickenpox had occurred but had not been reported at a specified age. Cases of chickenpox could not be validated by any independent procedure and therefore this study refers to "reported" chickenpox.

From the set of all the 49 factors significantly associated $(p<\cdot 05)$ with a history of chickenpox, groups were formed with a maximum of 10 independent categorical variables which were clearly related to one another through their subject similarity or through their chronological importance in development (table I). Recoding within variables was undertaken to group together adjacent or logically related levels that showed similar associations with chickenpox. Thus Yorkshire and the East Midlands were grouped together (similar chickenpox incidence and geographically close) but not with the South West despite similar rates of chickenpox. The six groups formed are listed in table I and forward stepping logistic regression by BMDP-PLR were undertaken, initially on each group separately, with chickenpox by age 10 as the dependent variable. The probability criterion for entering the model within each group was set at 0.01 and two moves were allowed into or out of the model in each round. Factors entering the model within each group are superscripted " 1 " in table I.

A hierarchical set of further regressions was then undertaken to eliminate covarying factors and select the most significant independent predictors of chickenpox. This was done initially by recombining groups using those factors entering the model in the initial round of the six logistic regressions. Factors in groups 1 and 2 (total $n=10$ ) and groups 4,5 , and 6 (total $n=10$ ) were combined into two new groups and a similar procedure was completed. Factors again entering the interim model from the two "second round" of regressions are superscripted " 2 " in table I. Group 3 factors were held over to be regressed together with those factors entering the interim model from groups 1 and 2 . Those entering the interim model on this occasion are superscripted " 3 " in table I. Finally, all the remaining 12 surviving factors from all the original groups were included in a single regression leaving six independent variables predictive of chickenpox by 10 years of age. These factors are superscripted " 4 " in table I (see discussion). The model produced by this procedure generated a decile based, Hosmer-Lemeshow goodness of fit $x^{2}$ of 8.4 with 8 degrees of freedom $(p=0.399)$ indicating a satisfactory fit. ${ }^{10}$

1958 NATIONAL COHORT STUDY (NCDS)

Factors similar to those determined to be most predictive of chickenpox by age 10 years in the 
1970 cohort data were identified in the 1958 cohort study. Equivalent variables were present in NCDS for "region of residence", "occupational class of father", "ethnic origin", and "interval between births". Similarity was assumed between the CHES factor "age mother left full-time education" and the dichotomised NCDS factor "did father stay at school past minimum school leaving age", as maternal and paternal educational levels usually correlate highly. Similarly, the CHES factor "number of persons in the household" (in 1975) was represented in NCDS analysis by the "number cooked for in household" at the beginning of the index pregnancy. Only cases for which information was available at both 7 and 11 years were used for analysis.

Levels within each background variable were combined according to the same principles as in the CHES cohort analysis and a single regression was performed with reported chickenpox by age 11 as the dependent variable.

\section{Results}

PREVALENCE

The history of chickenpox in young children from these two national cohort studies indicates that notwithstanding occasional epidemics, the underlying trend of chickenpox prevalence may have been down in the later study or that its age distribution had shifted. In NCDS by age 7 years, $61 \%$ of the cohort had been infected, increasing to $77 \%$ by age 11 years. In the CHES a total of $64 \%$ of the cohort were reported as having had the disease by age 10 years. The period of sus-

Table II Factors predictive of chickenpox by 10 years in the CHES cohort

\begin{tabular}{|c|c|c|c|c|}
\hline & $\begin{array}{l}\text { \% with } \\
\text { Chickenpox }\end{array}$ & $\begin{array}{l}\text { Adjusted } \\
\text { odds ratio }\end{array}$ & $(99 \% C I)$ & $x^{2}$ \\
\hline $\begin{array}{l}\text { Father's social class: } \\
\text { I } \\
\text { II } \\
\text { III (non-manual) } \\
\text { III (manual) } \\
\text { IV } \\
\text { V } \\
\text { Unsupported } \\
\text { Unknown }\end{array}$ & $\begin{array}{l}76 \cdot 7 \\
69 \cdot 0 \\
67 \cdot 6 \\
61 \cdot 7 \\
57 \cdot 6 \\
54 \cdot 7 \\
56 \cdot 8 \\
60 \cdot 9\end{array}$ & $\begin{array}{l}1 \cdot 50 \\
1 \cdot 17 \\
1 \cdot 13 \\
0 \cdot 98 \\
0 \cdot 89 \\
0 \cdot 80 \\
0 \cdot 83 \\
0 \cdot 97\end{array}$ & $\begin{array}{l}(1 \cdot 15,1.96) \\
(0.99,1.39) \\
(0.96,1.32) \\
(0 \cdot 87,1.09) \\
(0 \cdot 76,1.03) \\
(0.65,1 \cdot 00) \\
(0.62,1.11) \\
(0.64,1.20)\end{array}$ & $32 \cdot 98^{\star \star \star}$ \\
\hline $\begin{array}{l}\text { Ethnic origin: } \\
\text { European } \\
\text { Non-European, mixed } \\
\text { Unknown, not natural parents }\end{array}$ & $\begin{array}{l}63 \cdot 7 \\
41 \cdot 3 \\
63 \cdot 2\end{array}$ & $\begin{array}{l}1.28 \\
0.52 \\
1.50\end{array}$ & $\begin{array}{l}(1 \cdot 12,1 \cdot 46) \\
(0.42,0.65) \\
(1.27,1.78)\end{array}$ & $57 \cdot 91^{\star \star \star}$ \\
\hline $\begin{array}{l}\text { Region of birth: } \\
\text { Scotland } \\
\text { North, North West } \\
\text { Yorks and Humber, East Midlands } \\
\text { West Midlands } \\
\text { East Anglia, London } \\
\text { South East } \\
\text { South West } \\
\text { Wales }\end{array}$ & $\begin{array}{l}49 \cdot 8 \\
59 \cdot 7 \\
66 \cdot 1 \\
55 \cdot 1 \\
69 \cdot 6 \\
73 \cdot 0 \\
64 \cdot 1 \\
54 \cdot 1\end{array}$ & $\begin{array}{l}0 \cdot 61 \\
0 \cdot 93 \\
1 \cdot 25 \\
0 \cdot 82 \\
1 \cdot 44 \\
1 \cdot 59 \\
1 \cdot 05 \\
0 \cdot 72\end{array}$ & $\begin{array}{l}(0 \cdot 52,0 \cdot 71) \\
(0 \cdot 83,1 \cdot 05) \\
(1 \cdot 09,1 \cdot 43) \\
(0 \cdot 70,0 \cdot 95) \\
(1 \cdot 25,1 \cdot 67) \\
(1 \cdot 39,1 \cdot 81) \\
(0 \cdot 87,1 \cdot 27) \\
(0 \cdot 59,0 \cdot 87)\end{array}$ & $211 \cdot 73^{\star \star \star}$ \\
\hline $\begin{array}{l}\text { Mother's age }(y) \text { at leaving full-time ed } \\
\leq 14 \\
15 \\
16 \\
17,18 \\
\geq 19\end{array}$ & $\begin{array}{l}\text { tion: } \\
57 \cdot 9 \\
61 \cdot 1 \\
64 \cdot 9 \\
69 \cdot 4 \\
75 \cdot 4\end{array}$ & $\begin{array}{l}0 \cdot 72 \\
0 \cdot 89 \\
0 \cdot 97 \\
1 \cdot 13 \\
1 \cdot 43\end{array}$ & $\begin{array}{l}(0 \cdot 59,0 \cdot 88) \\
(0 \cdot 80,0.98) \\
(0.85,1 \cdot 11) \\
(0.97,1.32) \\
(1 \cdot 14,1 \cdot 78)\end{array}$ & $34 \cdot 48^{\star \star \star}$ \\
\hline $\begin{array}{l}\text { Interval between births }(y) \text { : } \\
\text { No previous pregnancies } \\
<2 \\
2-3 \\
3-5 \\
>5 \\
\text { Suspect dates/unknown }\end{array}$ & $\begin{array}{l}60 \cdot 2 \\
64 \cdot 8 \\
69 \cdot 0 \\
67 \cdot 1 \\
54 \cdot 4 \\
57 \cdot 5\end{array}$ & $\begin{array}{l}0 \cdot 91 \\
1 \cdot 12 \\
1 \cdot 25 \\
1 \cdot 22 \\
0 \cdot 76 \\
0 \cdot 85\end{array}$ & $\begin{array}{l}(0 \cdot 82,1.02) \\
(0.99,1.25) \\
(1.09,1.43) \\
(1.06,1.40) \\
(0.64,0.89) \\
(0.69,1.04)\end{array}$ & $56 \cdot 55^{\star \star \star}$ \\
\hline $\begin{array}{l}\text { No in household } \\
2,3 \\
4 \\
5 \\
\geq 6\end{array}$ & $\begin{array}{l}55 \cdot 4 \\
64 \cdot 7 \\
65 \cdot 5 \\
58 \cdot 7\end{array}$ & $\begin{array}{l}0 \cdot 80 \\
1 \cdot 07 \\
1 \cdot 16 \\
1 \cdot 00\end{array}$ & $\begin{array}{l}(0 \cdot 70,0 \cdot 93) \\
(0 \cdot 98,1 \cdot 17) \\
(1 \cdot 04,1 \cdot 28) \\
(0 \cdot 89,1 \cdot 13)\end{array}$ & $22 \cdot 16^{\star \star \star}$ \\
\hline
\end{tabular}

$\star \star \star=\mathrm{p}<0.001$

$\star$ Odds highlighted in bold deviate significantly $(p<0 \cdot 01)$ from 1. ceptibility for the CHES children (1970-80) included epidemics peaking in 1971 and $1980 .{ }^{4}$ Although no equivalent national data are available for the NCDS children between 1958 and 1966, the 1967 and 1968 chickenpox rates were relatively high and a slight trend towards a lower overall prevalence in the later period may be reasonably suspected. As discussed below a far higher proportion of the susceptible child population contracted chickenpox by 7 years in NCDS than in CHES. More recently a returning shift towards earlier infections has been proposed ${ }^{4}$ and this again seems to be associated with an increasing overall prevalence. ${ }^{11}$

No information on the precise age of contracting the disease is available from NCDS but CHES data on age specific rates recalled by the mother when the child was 10 years are probably reliable (figure). These show the exponential increase in susceptiblity to the disease up to age 10 when data collection ended.

FACTORS PREDICTIVE OF CHICKENPOX BY 10 YEARS (CHES)

The six factors independently predictive of reported chickenpox by age 10 years in the 1970 cohort are presented, together with the odds of chickenpox in each category and adjusted for other factors in the model, in table II. This table also lists the prevalence of chickenpox by age 10 in each level of each of the final model independent variables.

Taking the criteria of selection of categories whose $99 \%$ confidence intervals lie below or above unity, or whose trends across adjacent categories are clear, or both, conclusions about the social epidemiology of reported chickenpox by age 10 in the cohort can be drawn. Firstly, contracting chickenpox by 10 years of age shows a strong significant inverse association with occupational class of the father with an $87 \%$ higher odds of chickenpox by age 10 in children whose fathers were in the professional and managerial groups compared with unskilled labouring groups, when other factors are taken into account. European parents were two and a half times as likely to report chickenpox by age 10 in their children as non-Europeans or parents of mixed origin, whereas children whose parental ethnicity was not known or not stated also had a high odds of reported chickenpox. Chickenpox by 10 years was reported to be significantly more likely to occur in children who were delivered in the standard regions of Yorkshire and Humberside, East Midlands, East Anglia and the South East (including Greater London). The odds of the reported disease was twice as high in children whose mothers had left full-time education at 19 years or later compared with those who left at age 14 years. The adjusted odds of the disease was significantly and positively related to the interval between the birth (or end of pregnancy) of the previous and index children up to 5 years and significantly negatively related thereafter. First children were less likely to succumb to chickenpox but only at the $5 \%$ level of significance. A clearer pattern was presented by the association between chickenpox and the number of people in the household where a trend up to five persons was apparent but no higher. 


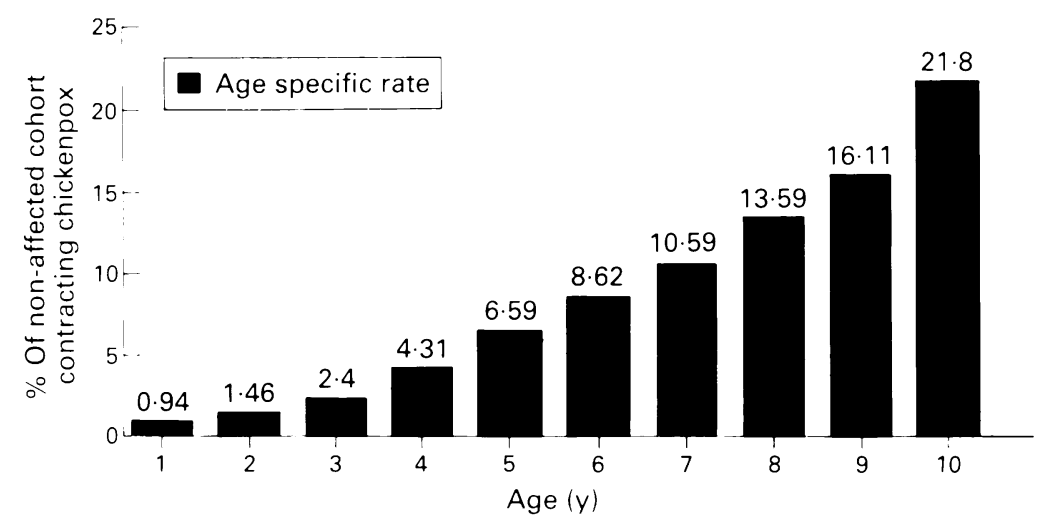

$(N=10196 ; N($ chickenpox $)=6174)$

Age specific infection rates for chickenpox (Child Health and Education Study)

Seen together the association between reported chickenpox by age 10 years and higher occupational class, European origin, longer maternal education, and longer birth spacing intervals are consistent with social conditions of advantage and relative affluence.

Further analysis was undertaken to obtain more detail on these relationships. The contingency that the disease was associated with urban life was assessed by reviewing the odds of chickenpox in both rural and urban communities as defined by the health visitor's report of the type of neighbourhood the child lived in at the age of 5 years. These indicate clearly that once an adjustment had been made for existing predictors no additional variance was explained by this factor (adjusted odds ratio of chickenpox in rural neighbourhoods $=1.00 ; 99 \%$ confidence interval $\left.0.94,1.08 ; x^{2}=0.14,1 \mathrm{df}, \mathrm{NS}\right)$. Secondly, the possibility that unadjusted regional groupings were distorting actual geographical patterns of the disease when controlled for other independent factors was examined by restoring the individual standard regions to the regression. This showed that no distortion had occurred and that all parts of the South and East had high levels of reported chickenpox infection by age 10 while Scotland and Wales were areas with the lowest geographical prevalence (table III).

CHICKENPOX BY AGE 11 IN THE NCDS COHORT When factors similar to those predictive of chickenpox by 10 years in the CHES cohort were applied to the NCDS data the results showed some similarity, although variation was noticeably

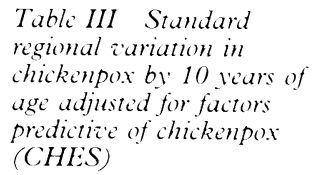

\begin{tabular}{|c|c|c|}
\hline & $\begin{array}{l}\text { Adjustid } \\
\text { odds rutio* }\end{array}$ & $\left(99^{\circ} \circ(I I)\right.$ \\
\hline Scotland & $0 \cdot 61$ & $(0 \cdot 51,0.72)$ \\
\hline $\begin{array}{l}\text { South Wales } \\
\text { North Wales }\end{array}$ & $\begin{array}{l}0.67 \\
0.78\end{array}$ & $\begin{array}{l}(0 \cdot 53,0 \cdot 86) \\
(0 \cdot 54,1 \cdot 12)\end{array}$ \\
\hline $\begin{array}{l}\text { North } \\
\text { Yorkshire, Humberside } \\
\text { North West } \\
\text { East Midlands } \\
\text { West Midlands } \\
\text { South West } \\
\text { East Anglia } \\
\text { South East } \\
\text { London }\end{array}$ & $\begin{array}{l}0.92 \\
1 \cdot 13 \\
0.89 \\
1 \cdot 30 \\
0 \cdot 80 \\
1 \cdot 04 \\
1 \cdot 36 \\
1 \cdot 56 \\
1 \cdot 46\end{array}$ & $\begin{array}{l}(0.76,1.12) \\
{[0.95,1.35)} \\
(0.77,1.04) \\
(1.05,1.63) \\
(0.68,0.94) \\
(0.85,1.27) \\
(1.03,1.79) \\
(1.35,1.80) \\
(1.22,1.74)\end{array}$ \\
\hline $\begin{array}{l}\text { No } \\
x^{2} 11 \mathrm{df} \\
\mathrm{p}\end{array}$ & $\begin{array}{l}10123 \\
209 \cdot 38 \\
<0.0001\end{array}$ & \\
\hline
\end{tabular}

less evident (table IV). Despite slightly different independent variable definitions there were higher odds in professional than in manual occupational classes, in Europeans than in non-Europeans, and in the economically privileged parts of the UK (South and East compared with the North, Scotland, and Wales). A weak positive association existed between chickenpox and the level of parental education. While in both cohorts the odds dropped with the longer pregnancy to birth intervals and the number of people in the household, both variables exhibiting $U$ shaped trends of association in both cohorts, the positions of the peaks and troughs differed slightly. Thus, the higher rate occurred when the interval between the end of the previous pregnancy and birth of the index child in CHES was two to three years whereas in NCDS it was one to two years. Both cohorts showed the drop in the odds of infection in the index child when the end of the previous pregnancy occurred at least five years before the index child's birth. For the number of household members, the CHES variable related to the "total number who live in the same address and are catered for by the same person" in 1975. For NCDS the comparable variable referred to the "number resident in the house at the beginning of pregnancy of the index child excluding lodgers and those eating separately". As $47 \%$ of the women in CHES had at least one child between 1970 and 1975 the category comparisons between the two cohorts should be adjusted for this factor. Furthermore, the ranges are different and it seems likely that this to some extent reflects changing living conditions (that is, improved housing) in the UK as a whole. Nevertheless the risk of reported chickenpox in small households seems to be higher (and in large households seems to be lower) in the NCDS cohort that in the CHES. This could be accounted for by the age distribution differences of reported chickenpox in the two cohorts (see below).

SPLIT AGE ANALYSIS ON THE TWO COHORTS

Because of the very high ultimate seroconversion rates in adult populations, which indicate prior chickenpox exposure or infection, or both, it is pertinent to question whether the social distribution we observed reflects trends in contracting the disease by a certain (that is, young) age rather than differences in overall susceptibility. To explore this contingency the odds of chickenpox were compared in the same factors for two different age groups in each cohort. For purposes of cohort comparison the 7 th birthdate was taken as the cohort dividing line for the two age groups. The proposed hypothesis was that if socially advantaged conditions were associated with chickenpox being contracted at earlier ages then the odds obtained for reported chickenpox infections at an earlier age would differ substantially from the odds of reported chickenpox at later ages, the former being more extreme in their social distribution.

The CHES cohort

Further separate logistic regressions using the same factors were run for those reported to have had the disease before and after their 7 th birthday 
Table IV Odds of a child having chickenpox by 11 years (NCDS) adjusted for factors independently predictive of chickenpox by 10 years (CHES).

\begin{tabular}{|c|c|c|c|c|}
\hline & $\begin{array}{l}\text { \% with } \\
\text { chickenpox }\end{array}$ & $\begin{array}{l}\text { Adjusted } \\
\text { odds ratio* }\end{array}$ & $(99 \% C I)$ & \\
\hline \multicolumn{5}{|l|}{ Father's social class: } \\
\hline I & $81 \cdot 4$ & $1 \cdot 11$ & $(0.83,1.49)$ & \\
\hline II & $81 \cdot 2$ & $1 \cdot 19$ & $(0.99,1.43)$ & \\
\hline III & $77 \cdot 5$ & $1 \cdot 05$ & $(0.93,1.19)$ & \\
\hline IV & $73 \cdot 0$ & 0.84 & $(0 \cdot 71,1 \cdot 00)$ & \\
\hline $\mathrm{V}$ & $72 \cdot 6$ & $0 \cdot 86$ & $(0 \cdot 71,1 \cdot 04)$ & \\
\hline No husband & $76 \cdot 0$ & 1.00 & $(0.67,1.48)$ & $x^{2}=19.63, p=0.0015$ \\
\hline \multicolumn{5}{|l|}{ Mother's place of birth: } \\
\hline European & $77 \cdot 2$ & $1 \cdot 12$ & $(0.88,1.41)$ & \\
\hline Non-European & $75 \cdot 4$ & $0 \cdot 89$ & $(0.71,1.13)$ & $\chi^{2}=1 \cdot 44, p=0 \cdot 2305$ \\
\hline \multicolumn{5}{|l|}{ Old standard region: } \\
\hline Scotland & $70 \cdot 7$ & $0 \cdot 74$ & $(0 \cdot 63,0 \cdot 86)$ & \\
\hline North Western & $76 \cdot 1$ & 0.95 & $(0 \cdot 81,1 \cdot 12)$ & \\
\hline \multirow{2}{*}{\multicolumn{5}{|c|}{ East/West Riding, North }} \\
\hline & & & & \\
\hline Midlands & $79 \cdot 4$ & $1 \cdot 16$ & $(0.99,1.35)$ & \\
\hline Midlands & $77 \cdot 3$ & $1 \cdot 04$ & $(0 \cdot 87,1 \cdot 24)$ & \\
\hline \multicolumn{5}{|l|}{ South East, South West, } \\
\hline London & $79 \cdot 9$ & $1 \cdot 17$ & $(1 \cdot 03,1 \cdot 34)$ & \\
\hline Southern & $82 \cdot 3$ & $1 \cdot 35$ & $(1.04,1 \cdot 74)$ & \\
\hline Eastern & $79 \cdot 9$ & $1 \cdot 15$ & $(0.94,1.42)$ & \\
\hline Wales & $73 \cdot 1$ & $0 \cdot 82$ & $(0.66,1.03)$ & $x^{2}=63.85, p<0.0001$ \\
\hline \multicolumn{5}{|c|}{ Did father stay at school after earliest school leaving age? } \\
\hline No & $76 \cdot 0$ & 0.93 & $(0 \cdot 86,1 \cdot 01)$ & \\
\hline Yes & $75 \cdot 0$ & 1.07 & $(0.99,1 \cdot 17)$ & $\chi^{2}=5 \cdot 11, p=0 \cdot 0238$ \\
\hline \multicolumn{5}{|c|}{ Last pregnancy to birth interval $(y)$ : } \\
\hline No previous pregnancies & $75 \cdot 7$ & 1.01 & $(0.83,1 \cdot 23)$ & \\
\hline 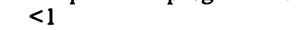 & $76 \cdot 6$ & 1.03 & $(0.72,1.47)$ & \\
\hline $1-2$ & $80 \cdot 3$ & $1 \cdot 24$ & $(1.07,1.44)$ & \\
\hline $2-3$ & $81 \cdot 0$ & $1 \cdot 21$ & $(1.03,1.43)$ & \\
\hline 3-4 & $78 \cdot 1$ & $1 \cdot 00$ & $(0.82,1.21)$ & \\
\hline $4-5$ & $76 \cdot 5$ & 0.93 & $(0 \cdot 74,1 \cdot 17)$ & \\
\hline$>5$ & $70 \cdot 7$ & 0.69 & $(0 \cdot 59,0.81)$ & $x^{2}=59 \cdot 34, p<0.0001$ \\
\hline \multicolumn{5}{|c|}{ No in household (excluding baby and lodgers) } \\
\hline None & $76 \cdot 5$ & $1 \cdot 13$ & $(0 \cdot 87,1 \cdot 46)$ & \\
\hline 1,2 & $75 \cdot 1$ & 1.01 & $(0.84,1.21)$ & \\
\hline 3 & $82 \cdot 1$ & $1 \cdot 51$ & $(1 \cdot 31,1 \cdot 74)$ & \\
\hline $4-5$ & $76 \cdot 5$ & $1 \cdot 15$ & $(1 \cdot 00,1 \cdot 33)$ & \\
\hline $6-7$ & $72 \cdot 9$ & 0.96 & $(0.78,1.18)$ & \\
\hline $8+$ & $60 \cdot 5$ & 0.53 & $(0.40,0 \cdot 70)$ & $x^{2}=77 \cdot 76, p<0.0001$ \\
\hline
\end{tabular}

${ }^{\star}$ Odds significantly $(\mathrm{p}<0.01)$ deviant from 1 are in bold.

Table $V$ Comparison of odds of chickenpox (CHES) at different ages adjusted for predictors of chickenpox by 10 years (CHES)

\begin{tabular}{|c|c|c|c|c|}
\hline & \multicolumn{2}{|c|}{ Chickenpox $<7 y$} & \multicolumn{2}{|c|}{ Chickenpox 7-10y } \\
\hline & $\begin{array}{l}\text { Adjusted odds } \\
\text { ratio }\end{array}$ & $(99 \% C I)$ & & $(99 \% C I)$ \\
\hline $\begin{array}{l}\text { ather's occupational class: } \\
\text { I } \\
\text { II } \\
\text { IIINM } \\
\text { IIIM } \\
\text { IV } \\
\text { V } \\
\text { No father figure } \\
\text { Not known }\end{array}$ & $\begin{array}{l}1 \cdot 40 \\
1 \cdot 13 \\
1 \cdot 08 \\
0 \cdot 96 \\
0 \cdot 82 \\
0 \cdot 79 \\
0 \cdot 91 \\
1 \cdot 03 \\
\chi^{2}=29 \cdot 1,7 \mathrm{df},\end{array}$ & $\begin{array}{l}(\mathbf{1} \cdot 11,1 \cdot 78) \\
(0.96,1.34) \\
(0.91,1.27) \\
(0.85,1.08) \\
(0.70,0.97) \\
(0.62,1.01) \\
(0.66,1.27) \\
(0.74,1.42) \\
\text { p=0.0001 }\end{array}$ & $\begin{array}{l}1 \cdot 35 \\
1 \cdot 15 \\
1 \cdot 13 \\
1 \cdot 00 \\
0 \cdot 96 \\
0 \cdot 86 \\
0 \cdot 82 \\
0 \cdot 83 \\
\chi^{2}=14 \cdot 81,7 \mathrm{~d}\end{array}$ & $\begin{array}{l}(1 \cdot 00,1 \cdot 82) \\
(0.94,1.36) \\
(0.94,1.36) \\
(0.88,1.13) \\
(0.81,1 \cdot 14) \\
(0.67,1.11) \\
(0.59,1.16) \\
(0.58,1.21) \\
p=0.0385\end{array}$ \\
\hline $\begin{array}{l}\text { arent's ethnic origin: } \\
\text { European } \\
\text { Non-european } \\
\text { Unknown/adopted }\end{array}$ & $\begin{array}{l}1 \cdot 17 \\
0 \cdot 63 \\
1 \cdot 36 \\
x^{2}=23 \cdot 41,2 \mathrm{~d}\end{array}$ & $\begin{array}{l}(1 \cdot 01,1 \cdot 36) \\
(0.48,0.82) \\
(1 \cdot 13,1.64) \\
f, p<0.0001\end{array}$ & $\begin{array}{l}1 \cdot 27 \\
0 \cdot 55 \\
1 \cdot 44 \\
x^{2}=35 \cdot 01,2 d\end{array}$ & $\begin{array}{l}(1 \cdot 08,1 \cdot 49) \\
(0.42,0 \cdot 72) \\
(1 \cdot 17,1 \cdot 75) \\
p<0.0001\end{array}$ \\
\hline $\begin{array}{l}\text { Region of child's delivery: } \\
\text { Scotland } \\
\text { North/North West } \\
\text { Yorks and Humb/East Midlands } \\
\text { West Midlands } \\
\text { East Anglia/London } \\
\text { South East } \\
\text { South West } \\
\text { Wales }\end{array}$ & $\begin{array}{l}0 \cdot 73 \\
0.91 \\
1.08 \\
0.98 \\
1 \cdot 49 \\
1 \cdot 47 \\
0.99 \\
0 \cdot 65 \\
x^{2}=137 \cdot 09,7\end{array}$ & $\begin{array}{l}(0 \cdot 61,0.88) \\
(0.80,1.04) \\
(0.94,1.25) \\
(0.83,1.16) \\
(1 \cdot 30,1 \cdot 72) \\
(1 \cdot 29,1.67) \\
(0.81,1.21) \\
(0.51,0.82) \\
\text { df, p<0.0001 }\end{array}$ & $\begin{array}{l}\mathbf{0 \cdot 6 2} \\
0 \cdot 97 \\
\mathbf{1} \cdot 29 \\
\mathbf{0} \cdot 77 \\
\mathbf{1} \cdot 27 \\
\mathbf{1} \cdot 45 \\
1 \cdot 09 \\
0 \cdot 82 \\
\chi^{2}=119 \cdot 38,7\end{array}$ & $\begin{array}{l}(0 \cdot 52,0 \cdot 75) \\
(0 \cdot 85,1 \cdot 17) \\
(1 \cdot 10,1 \cdot 50) \\
(0 \cdot 64,0 \cdot 92) \\
(1.07,1 \cdot 50) \\
(1 \cdot 25,1 \cdot 70) \\
(0.88,1 \cdot 36) \\
(0.66,1.03) \\
\text { df, } p<0.0001\end{array}$ \\
\hline $\begin{array}{l}\text { Ige mother left full-time education } \\
\leq 14 \\
15 \\
16 \\
17,18 \\
\geq 19\end{array}$ & $\begin{array}{l}(y): \\
0 \cdot 75 \\
0 \cdot 89 \\
0 \cdot 95 \\
1 \cdot 15 \\
1 \cdot 38 \\
x^{2}=30 \cdot 59,4 d\end{array}$ & $\begin{array}{l}(0.60,0.93) \\
(0.80,0.99) \\
(0.83,1.09) \\
(0.99,1.34) \\
(1.13,1.69) \\
f, p<0.0001\end{array}$ & $\begin{array}{l}0 \cdot 78 \\
0 \cdot 92 \\
1 \cdot 00 \\
1 \cdot 08 \\
1 \cdot 29 \\
x^{2}=13 \cdot 07,4 d\end{array}$ & $\begin{array}{l}(0.62,0.99) \\
(0 \cdot 81,1 \cdot 03) \\
(0.86,1 \cdot 16) \\
(0.91,1 \cdot 30) \\
(1.00,1 \cdot 66) \\
f, p=0.0109\end{array}$ \\
\hline $\begin{array}{l}\text { Last pregnancy to birth interval }(y) \text { : } \\
\text { No previous pregnancies } \\
<2 \\
2-3 \\
3-5 \\
>5 \\
\text { Not known/uncertain }\end{array}$ & $\begin{array}{l}0 \cdot 64 \\
1.00 \\
1 \cdot 22 \\
1 \cdot 39 \\
0.95 \\
0.97 \\
x^{2} 142 \cdot 19,5 \mathrm{df}\end{array}$ & $\begin{array}{l}(0 \cdot 57,0 \cdot 72) \\
(0 \cdot 89,1 \cdot 13) \\
(1 \cdot 07,1 \cdot 39) \\
(1 \cdot 21,1 \cdot 59) \\
(0 \cdot 80,1 \cdot 13) \\
(0 \cdot 79,1 \cdot 21) \\
\text {, p<-0001 }\end{array}$ & $\begin{array}{l}1 \cdot 15 \\
1 \cdot 19 \\
1 \cdot 20 \\
1 \cdot 07 \\
0 \cdot 70 \\
0 \cdot 82 \\
x^{2}=38 \cdot 34,5 \mathrm{~d}\end{array}$ & $\begin{array}{l}(\mathbf{1} \cdot 01,1 \cdot 30) \\
(\mathbf{1 \cdot 0 4}, \mathbf{1} \cdot \mathbf{3 6}) \\
(\mathbf{1} \cdot 02,1 \cdot 40) \\
(0 \cdot 90,1 \cdot 26) \\
(0 \cdot 57,0 \cdot 85) \\
(0.64,1 \cdot 05) \\
f, p<0.0001\end{array}$ \\
\hline $\begin{array}{l}\text { No in household: } \\
2 \text { or } 3 \\
4 \\
5 \\
\geq 6\end{array}$ & $\begin{array}{l}0.94 \\
0.95 \\
1 \cdot 07 \\
1.05 \\
\chi^{2}=5 \cdot 64,3 \mathrm{df},\end{array}$ & $\begin{array}{l}(0.80,1.10) \\
(0.87,1.04) \\
(0.96,1.19) \\
(0.92,1.19) \\
p=0.1305\end{array}$ & $\begin{array}{l}0.79 \\
1.13 \\
1 \cdot 17 \\
0.95 \\
\chi^{2}=24 \cdot 52,3 \mathrm{df} \\
\end{array}$ & $\begin{array}{l}(0 \cdot 67,0.93) \\
(1 \cdot 02,1 \cdot 25) \\
(1 \cdot 04,1 \cdot 32) \\
(0.85,1 \cdot 10) \\
p=0.00016\end{array}$ \\
\hline
\end{tabular}

*Values significantly different from 1 given in bold. (table V). Approximately one half the cases of chickenpox in this cohort occurred in each of the two time periods. The cases used in these logistic regressions were cases before the 7 th birthday compared with all those who had not contracted the disease by age 7 (the at risk population), and cases between 7 and 10 years compared with all those who had not contracted chickenpox by 10 (the at risk population).

The results indicate that the same social trends already reported characterise the incidence of the disease over both age periods. Patterns of association between reported chickenpox and father's occupational class, ethnic origin, maternal education, and geographical region were similar in the two age groups. Relationships with birth interval and household size, however, differed. Index children were more likely to catch the disease earlier if their next oldest sibling was at least two years older with a peak at three to five years difference in ages. Those index children who caught chickenpox later, however, were more likely to have older siblings closer in age to themselves. This may reflect the higher susceptibility of 2,3 , or 4 years olds to infection from older siblings returning home from school compared with the 6 or 7 year old whose exposure derives more from classmates.

The NCDS cohort

A similar analysis was conducted on the NCDS chickenpox data. Cases of chickenpox by 7 years and between 7 and 11 years were compared with the rest of the population at risk for their association with the same set of background factors found to be predictive of chickenpox by 10 years in CHES. In this analysis cases of reported chickenpox by 7 years which were denied at age 11 years $(n=500)$ were omitted on the basis that the precise age of the child's chickenpox was uncertain. The "split age" analysis on the NCDS cohort produced less informative results (table VI). In NCDS, significant ( $p<0.01)$ variation for each independent variable was reached only for "region of birth" and "household size" (both 0-7 years chickenpox), and for "birth interval" (both age groups). For chickenpox between 0 and 7 years the higher odds in London, the South East, and South West and the lower odds in Scotland reached significance at the $1 \%$ level, with low odds in Wales falling between the $5 \%$ and $1 \%$ significance bands. For the children who caught chickenpox after age 7 years, significantly $(p<0.01)$ high odds were seen in the Southern region with low odds is Scotland and Northern standard regions approaching significance $(p<0.05)$. These results are broadly consistent with those of CHES and argue against a strong interaction between the age of infection and background social factors, although a trend towards the weakening of the odds in the older age group exists. For both age groups the birth interval remained a significant factor in the distribution of chickenpox in the population. As in the CHES data, the first child was protected against early but not later infection, with a sibling aged one to five years older increasing the odds of an early infection. Household size was a significant factor only for early chickenpox infection and was apparently more important than in CHES. 
Direct comparison of the CHES and NCDS results are confounded by the appreciably different age specific susceptibility of chickenpox in the two cohorts. Although the prevalences of reported chickenpox by age 10 years in CHES $(62 \%)$ and by 11 years in NCDS $(77 \%)$ were not too dissimilar, the proportions of the population with a reported history of the disease by age 7 years differed substantially (CHES $30.4 \%$, NCDS $61 \cdot 8 \%$ ).

\section{Discussion}

The data presented seem to indicate that reported chickenpox infections more commonly affect the more advantaged sectors of society. Furthermore, the risk of contraction of the disease in early childhood is slightly more dependent on social factors that later infections although similar trends are apparent. These data are distinct from another common infectious disease, measles, whose social distribution clearly follows lines of deprivation and poorer economic circumstances. ${ }^{12}$ What explanations can account for this pattern?

One possibility that urban lifestyle is implicated has already been discounted as unlikely. Another is that reports of chickenpox are positively biased in the better educated, socially advantaged sectors of the population. This could be the case, for example, if other social groupings ignore or fail to

Table VI Odds of chickenpox at different ages (NCDS) adjusted for factors independently predictive of chickenpox by 10 years (CHES)

\begin{tabular}{|c|c|c|c|c|}
\hline & \multicolumn{2}{|c|}{ Chickenpox $<7 y$} & \multicolumn{2}{|c|}{ Chickenpox 7-11y } \\
\hline & $\begin{array}{l}\text { Adjusted odds } \\
\text { ratio }\end{array}$ & $(99 \% C I)$ & $\begin{array}{l}\text { Adjusted odds } \\
\text { ratio }\end{array}$ & $(99 \% C I)$ \\
\hline \multicolumn{5}{|l|}{ Father's social class: } \\
\hline & $0 \cdot 89$ & $(0 \cdot 70,1 \cdot 14)$ & $1 \cdot 14$ & $(0 \cdot 79,1 \cdot 66)$ \\
\hline II & $1 \cdot 11$ & $(0.95,1.29)$ & $1 \cdot 15$ & $(0.90,1.46)$ \\
\hline III & 1.08 & $(0.97,1.21)$ & 0.99 & $(0.84,1 \cdot 17)$ \\
\hline IV & 0.94 & $(0 \cdot 80,1 \cdot 10)$ & 0.90 & $(0.71,1.13)$ \\
\hline V & 1.01 & $(0 \cdot 85,1 \cdot 20)$ & $0 \cdot 82$ & $(0.62,1.07)$ \\
\hline No husband & $\begin{array}{l}0.98 \\
x^{2}=9 \cdot 37, p=0\end{array}$ & $\begin{array}{l}(0.69,1 \cdot 39) \\
.0953\end{array}$ & $\begin{array}{l}1 \cdot 05 \\
x^{2}=7 \cdot 05, p=0.2\end{array}$ & $\begin{array}{l}(0.63,1 \cdot 76) \\
.2167\end{array}$ \\
\hline \multicolumn{5}{|l|}{ Mother's place of birth: } \\
\hline European & 1.03 & $(0 \cdot 83,1 \cdot 26)$ & 0.92 & $(0.66,1.28)$ \\
\hline Non-Eurpean & $\begin{array}{l}0.97 \\
x^{2}=0.05, p=0 .\end{array}$ & $\begin{array}{l}(0 \cdot 79,1 \cdot 20) \\
8151\end{array}$ & $\begin{array}{l}1.09 \\
\chi^{2} 0 \cdot 49, p=0.49\end{array}$ & $\begin{array}{l}(0 \cdot 78,1.52) \\
929\end{array}$ \\
\hline \multicolumn{5}{|l|}{ Old standard region: } \\
\hline Scotland & 0.85 & $(0.73,0.98)$ & $0 \cdot 84$ & $(0.68,1 \cdot 04)$ \\
\hline North Western & 1.04 & $(0.91,1.20)$ & 0.90 & $(0.73,1.13)$ \\
\hline \multirow{2}{*}{\multicolumn{2}{|c|}{ East and West Rid, North }} & $(0.79,1 \cdot 11)$ & $0 \cdot 78$ & $(0.60,1.02)$ \\
\hline Midlands & $1 \cdot 12$ & $(0.98,1.28)$ & 1.05 & \\
\hline Midlands & 1.07 & $(0.91,1.25)$ & 0.99 & $(0.78,1.27)$ \\
\hline Eastern & $1 \cdot 01$ & $(0.85,1 \cdot 20)$ & 1.09 & $(0.83,1.43)$ \\
\hline \multicolumn{5}{|l|}{ South East, South West, } \\
\hline $\begin{array}{l}\text { London } \\
\text { Southern }\end{array}$ & $1 \cdot 13$ & $(1 \cdot 01,1 \cdot 26)$ & 1.05 & $(0 \cdot 88,1 \cdot 26)$ \\
\hline $\begin{array}{l}\text { Southern } \\
\text { Wales }\end{array}$ & 1.03 & $(0 \cdot 84,1 \cdot 27)$ & $1 \cdot 42$ & $(1 \cdot 02,1.98)$ \\
\hline & $\begin{array}{l}0.86 \\
\chi^{2}=24 \cdot 76, p=c\end{array}$ & $0 \cdot 0017$ & $\begin{array}{l}0 \cdot 99 \\
\chi^{2}=17 \cdot 66, p=0\end{array}$ & $\begin{array}{l}(0 \cdot 73,1 \cdot 34) \\
0 \cdot 0236\end{array}$ \\
\hline \multicolumn{5}{|c|}{ Did father stay at school after earliest school leaving age? } \\
\hline No & 0.96 & $(0.89,1.03)$ & 0.96 & $(0 \cdot 86,1 \cdot 07)$ \\
\hline Yes & $\begin{array}{l}1 \cdot 04 \\
\chi^{2}=2 \cdot 45, p=0\end{array}$ & $\begin{array}{l}(0 \cdot 97,1 \cdot 12) \\
\cdot 1173\end{array}$ & $\begin{array}{l}1 \cdot 04 \\
\chi^{2}=0 \cdot 79, p=0\end{array}$ & $\begin{array}{l}(0.93,1 \cdot 16) \\
3726\end{array}$ \\
\hline \multicolumn{5}{|c|}{ Last pregnancy to birth interval $(y)$ : } \\
\hline No previous pregnancies & $0 \cdot 70$ & $(0.59,0.84)$ & $1 \cdot 17$ & $(0.90,1.52)$ \\
\hline$<1$ & $1 \cdot 13$ & $(0.82,1.54)$ & 1.07 & $(0.64,1 \cdot 80)$ \\
\hline $1-2$ & $1 \cdot 26$ & $(1 \cdot 11,1 \cdot 43)$ & $1 \cdot 20$ & $(0.97,1.48)$ \\
\hline $2-3$ & $1 \cdot 17$ & $(1 \cdot 01,1 \cdot 35)$ & $1 \cdot 10$ & $(0 \cdot 87,1 \cdot 40)$ \\
\hline $3-4$ & $1 \cdot 19$ & $(1 \cdot 00,1 \cdot 41)$ & $0 \cdot 82$ & $(0.61,1.09)$ \\
\hline $4-5$ & 1.09 & $(0 \cdot 88,1 \cdot 34)$ & 0.90 & $(0.64,1 \cdot 27)$ \\
\hline$>5$ & $0 \cdot 66$ & $(0.57,0.77)$ & $0 \cdot 82$ & $(0.65,1.03)$ \\
\hline & $x^{2}=116 \cdot 84, \mathrm{p}$ & $<0.0001$ & $x^{2}=17 \cdot 02, \mathrm{p}=0$ & 0.0092 \\
\hline \multicolumn{5}{|c|}{$\begin{array}{l}\text { No in household excluding baby and lodgers): } \\
\text { None }\end{array}$} \\
\hline None & 1.01 & $(0 \cdot 81,1 \cdot 27)$ & $1 \cdot 18$ & $(0.84,1 \cdot 65)$ \\
\hline 1,2 & 0.98 & $(0.84,1 \cdot 15)$ & 1.00 & $(0 \cdot 79,1 \cdot 26)$ \\
\hline 3 & $1 \cdot 50$ & $(1 \cdot 32,1 \cdot 69)$ & 1.09 & $(0.89,1.32)$ \\
\hline $4-5$ & $1 \cdot 18$ & $(1 \cdot 04,1 \cdot 34)$ & 1.03 & $(0 \cdot 84,1 \cdot 25)$ \\
\hline $6-7$ & $0 \cdot 87$ & $(0 \cdot 66,1 \cdot 15)$ & $1 \cdot 11$ & $(0.83,1.49)$ \\
\hline $8+$ & $\begin{array}{l}0 \cdot 66 \\
x^{2}=80 \cdot 16, p<c\end{array}$ & $(0.50,0.87)$ & 0.69 & $(0.45,1.04)$ \\
\hline & $x^{2}=80 \cdot 16, \mathrm{p}<c$ & 0.0001 & $x^{2}=7 \cdot 3$ & 1956 \\
\hline
\end{tabular}

recognise the disease when symptoms are mild. However, although this factor might be responsible for social bias in seeking medical attention, it is much less likely to significantly affect responses to questions asked by health professionals in the home. The CHES questionnaire furthermore, had a "Not Known" category which, unless the mother was certain the child had either had or not had chickenpox, was available for recording an uncertain response. The proportion of "not known" reponses was only $1 \cdot 2 \%(n=121)$.

Alternatively, chickenpox may have a higher real prevalence in the more privileged groups. This was apparently the case, for example, for cases of appendicitis and paralytic poliomyelitis in the past. For appendicitis higher rates of subclinical infection (and hence immunological protection) in early childhood in poorer socioeconomic groups, because of more insanitary living conditions, statistically contrasted with reduced immunity and therefore increased susceptibility to acute disease in more advantaged sectors in society as domestic conditions improved. ${ }^{12} 13$ Should such a phenomenon apply to chickenpox, social stratification in titres of varicella-zoster immunoglobulin should be demonstrable in infancy.

IgG antibody to varicella-zoster virus antigen has been detected in the umbilical cord sera of infants delivered of women with maternal IgG antibody of a similar concentration assessed at delivery. ${ }^{14}$ This raises another epidemiological possibility-that women re-exposed to chickenpox in adulthood may be boosting an immunological response that is transferred passively to the fetus during pregnancy. Should this form of adult exposure be more prevalent in poorer socioeconomic groups then an epidemiological pattern like that of polio may emerge. There is no evidence, however, that late transfer of passive immunity from breast feeding confers any protection against chickenpox either in the population as a whole or in socially disadvantaged groups. In the CHES cohort chickenpox rates by age 10 years in breast-fed children who were born into socially disadvantaged circumstances according to a social index scale ${ }^{15}$ were similar to a comparable bottle-fed group $\left(x^{2}=0.41,1 \mathrm{df}\right.$, $\mathrm{p}=0.524$ ).

Within the United Kingdom, regional variation in the prevalence of reported chickenpox illustrated by these data may be consistent with other reports about the international geographical distribution of the disease and the age at which it occurs. It has been known for some time that exposure to varicella in the industrialised world, as measured by a reported history of infection or the presence of anti-varicella antibodies, is almost universal by early middle age. In Britain, studies have shown that almost $80 \%$ of children are seropositive by 15 years of age ${ }^{16}$ while in the United States $82 \%$ of infections are recorded in children by 9 years ${ }^{6}$ and seroreactivity in urban, native born people approaches $100 \%$ by age $60 .^{17}$ In Japan, seropositivity plateaued at $100 \%$ at 25 years of age. ${ }^{18}$

Unlike measles, however, which is almost universally a disease of early childhood throughout the world, there are accumulating reports of 
different chickenpox age distributions in tropical countries of the South compared with the temperature North. Studies conducted both within developing countries themselves and those reporting the susceptibility to chickenpox of migrants from those countries in the North support this conclusion. The mean age of chickenpox in one small West Bengal village was 23.4 years with $63 \%$ of cases over $15 .{ }^{19}$ In Somalia $46 \%$ of cases occurred in people over the age of $15 .^{20}$ Adolescent and young adult creoles in French Guiana were the most susceptible groups according to Poveda $e t a l^{21}$ and Barss ${ }^{22}$ documented the susceptibility of adults in Papua New Guinea and its islands to chickenpox infections. In Angoda, Sri Lanka, hospital admission records between 1955 and 1959 showed that $71.5 \%$ of chickenpox cases were aged 20 or over. ${ }^{23}$ Only $30 \%$ of student nurses aged 17-20 years possessed complement fixation antibodies to varicella-zoster antigen in Vellore, India ${ }^{24}$ compared with $70-100 \%$ of similar age groups in England, ${ }^{25}$ the United States, ${ }^{26}$ and Canada. ${ }^{27}$

Visitors to western countries from the tropics may be poorly protected against the disease and there are well documented outbreaks of chickenpox in Sri Lankan refugees ${ }^{28}$ and Puerto Rican army recruits. ${ }^{29}$ Nosocomial chickenpox infections affecting immigrant nurses from Sri Lanka and India ${ }^{30}$ and the Philippines ${ }^{31}$ have also been reported. It may be no coincidence that most of these reports relate to islands where the circulation and transmission of the virus may be reduced. Alternatively, it raises the possibility that early exposure to varicella is associated with a more industrialised lifestyle, better conditions of sanitation and nutrition, and economically advantaged living conditions.

While inhabitants of tropical islands may be less exposed to the disease and may contract it late, if at all, this epidemiological pattern, together with the strong seasonal peaks in winter and spring, ${ }^{31} 32$ suggests that both ambient heat and humidity are associated with constraints on the activity of the virus. While seasonal patterns in infection may reflect changes in human behaviour, viral transmission or infectivity, or both, may be sensitive to environmental conditions. It has been suggested, for example, that varicella-zoster virus is sensitive to high ambient temperature ${ }^{33}$ and according to Venkitarama and $\mathrm{John}^{23}$ varicella seems to be relatively uncommon in India in the hot months. Mean monthly chickenpox admission to the Fever Hospital in Angoda, Sri Lanka, during the hot monsoon period between 1955 and 1959 was $300 \cdot 5$ compared with the cooler dry season figure of $664 .^{23}$ The geographical prevalence figures determined in the present study and the regional death rates secondary to chickenpox between 1967 and 1985 prepared by the CDSC (Joseph personal communication) are consistent with a west (low) - east (high) gradient and a more efficient transmission in the drier parts of the UK. Tropical islands may not only constitute physical barriers to transmission but are also notably humid throughout the year.

A quite different hypothesis has been presented by Sinha ${ }^{19}$ who adopted the "epidemiological interference" hypothesis of Bang ${ }^{34}$ to propose that the high prevalence in early childhood of respira- tory Herpes infections in some developing countries, together with a degree of conferred, cross specific serological protection, postpones chickenpox infection to a later stage. The patchy serological profile data from the developing world, however, is more consistent with a lack of exposure to the antigen itself.

In conclusion the social epidemiology of chickenpox in two large representative cohorts of British schoolchildren shows patterns of susceptibility linked to measures of social advantage. The international distribution of chickenpox may reflect a similar trend on a wider scale, although it is possible that climatological parameters may also be involved. More research is indicated in accounting for these findings in view of the move towards providing a vaccination service against varicella-zoster. It would seem to be appropriate to recommend the closer monitoring of the disease in the UK before and in the event of a widespread vaccination service in order to assess differential susceptibility and to evaluate the immunisation protocols.

We are grateful for the comments of Dr Mike Wadsworth on an earlier draft of this manuscript. This work was undertaken with the support of the Health Promotion Research Trust.

1 Guess HA, Broughton DD, Melton LJ, Kurland LT Population-based studies of varicella complications. Pediatrics 1986: 78: 723-7.

2 Geld LD, Huang JJ, Wellinghoff WJ. Varicella-zoster virus transformation of hamster embryo cells. $\mathcal{F}$ Gen Virol 1980 51: $171-7$.

3 Yaminishi K, Matsunaga Y, Ogino Y, Lopetegui P. Biochemical transformation of mouse cells by varicellazoster virus. f Gen Virol 1980; 56: 421-30.

4 Joseph C, Noah N. Epidemiology of chickenpox in England and Wales, 1967-1985. BMF 1988; 296: 673-6.

5 Sullivan-Bolyai JZ, Y in EK, Cox P, Marchand A, Meissinger J, Venerable L, Weiss B. Impact of chickenpox on households of healthy children. Pediatr Infect Dis $\mathcal{f} 1987$; 6: 33-5.

6 Weller TH. Varicella and Herpes zoster. N Eng $\mathcal{F}$ Med 1983; 309: 1362-68.

7 Chamberlain R, Chamberlain G, Howlett B, Claireaux A. The first week of life. London: Heinemann Medical Books, 1975. (British Births 1970; Vol 1)

8 Chamberlain G, Philipp E, Howlett B, Masters K. Obstetric care. London: Heinemann Medical Books, 1978. (British Births 1970; vol 2).

9 Davie R, Butler N, Goldstein H. From birth to seven: $A$ report of the national child development study. London: Longman 1972.

10 Hosmer DW, Lemeshow S. Applied logistic regression. New York: Jon Wiley and Sons, 1989

11 Fleming DM, Crombie DL. Annual and seasonal variation in the incidence of common diseases RCGP occasional paper 53.1. London: Royal College of General Practitioners, 1995.

12 Barker $D$. Acute appendicitis and dietary fibre: an alternative hypothesis. $B M \mathcal{F}$ 1985; 290: 1125-7.

13 Barker DJP, Osmond C, Golding J, Wadsworth MEJ. Acute appendicitis and bathrooms in three samples of British children. $B M \mathcal{F}$ 1988; 296: 956-8.

14 Brunell PA, Gershon A, Uduman SA, Steinberg S. VaricellaZoster immunoglobulins during varicella, latency and Zoster immunoglobulins 132: 49-54.

15 Osborn AF, Morris TC. The rationale for a composite index of social class and its evaluation. BrF Sociol 1979; 30: 39-60.

6 Heath RB. Varicella-zoster. In: Zuckerman AJ, Banatvala JE, Heath RB. Varicella-zoster. In: Zuckerman AJ, Banatvala eds. Principles

17 Gershon AA, Steinberg S. Antibody responses to varicellaGershon AA, Steinberg $\mathrm{S}$. Antibody responses to varicella-
zoster virus and the role of antibody in host defense. $A m \mathcal{F}$ zoster virus and the role of
$M e d$ ci 1981; 282: 12-17.

18 Taylor-Wiedeman J, Yamashita K, Mitamura K, Yamazaki $S$. Varicella-zoster virus prevalence in Japan: no significant change in a decade. Fapanese fournal of Medicine Science and Biology 1989; 42: 1-11.

19 Sinha DP. Chickenpox-A disease predominantly affecting adults in rural West Bengal. Int $\mathcal{F}$ Epidemiol 1976; 5: 367-74.

20 Jezek Z, Hardjotanojo W, Rangaraj AG. Facial scarring after varicella: a comparison with variola major and variola minor. Am f Epidemiol 1981; 114: 798-803.

21 Povada JD, Babin M, Bonnici JF, du Pasquier P, Fleury HJ. Serological study of the occurrence of Herpesviridae in French Guyana (In French) Bull Soc Pathol Exot Filiales 1986; 79: 207-12. 
22 Barss P. Deaths from chickenpox in adults in Papua New Guinea. Lancet 1983; i(8316): 126

23 Maretic Z, Cooray MPM. Comparisons between chickenpox in a tropical and a European country. $\mathcal{F}$ Trop Med Hygiene 1963; 66: 311-15.

24 Venkitaraman AR, John TJ. The epidemiology of varicella in staff and students of a hospital in the tropics. Int $\mathcal{F}$ Epidemiol 1984; 13: 502-5. 5 Tomlinson

The incidence of complement fxing antibody to varicella-zoster virus in hospital patients and bi

6 Wentworth BB, Alexander SR. Seroepidemiology of infections due to members of herpes virus group. Am $\mathcal{f}$ Epidemiology 1971; 94: 496-507.

27 Wong CL, Castriciano S, Chernesky MA, Rawls WE Quantitation of antibodies to varicella-zoster virus by immune adherence hemagglutination. $f$ Clin Microbio 1978; 7: 6-11
28 Kjersem H, Jepsen S. Varicella among immigrants from the 29 Lonofield JN, Winn RE Gibson RI Juchau SV, Hoffman PV. Varicella outbreaks in army recruits from Puerto Varicella susceptibility in army recruits from Puerto Rico. Arch Int Med 1990; 150: 970-3. 30 Hastie IR. Varicella-zoster virus affecting immigrant nurses. Lancet 1980; ii: 154-5.

31 Nassar NT, Touma HC. Susceptibility of Filipino nurses to the varicella-zoster virus. Inf Control 1985; 7: 51-2.

32 Gordon JE. Chickenpox, an epidemiologic review. $A m \mathcal{F} \mathrm{Med}$ Sci 1962; 224: 362-89.

33 Weller TH. Varicella-zoster virus. In: Evans AS ed. Viral infections of humans: epidemiology and control. New York: Plenum Medical Book Co, 1976; 460-75.

34 Bang FB, Epidemiological Interference. Int $f$ Epidemiol $1975 ;$ 4(4): 337-42. 